\title{
'for their own purposes of identity': Tom Stannage and Australian Local History
}

\author{
DAVID CARMENT
}

$\mathrm{A}$ ustralian local history was only one of the areas where Tom Stannage made a significant contribution but he regularly returned to it throughout his career, frequently speaking and writing about the local past and collaborating with the community organisations that promoted it. He passionately believed that an understanding of local history allowed Australians to answer fundamental questions regarding the nature of life and who they were. ${ }^{1}$ It was about, as he wrote in 1979, ' placing life experiences in a meaningful social context' and was an essentially democratic process. While his own approach emphasised 'the acquisition, maintenance and exercise of power, and the social consequences of its distribution', there were as many histories of any particular locality 'as there are people writing or talking about it... that is how should be. That is how it can 
only be'. ${ }^{2}$ In the context of Stannage's perspectives, the work of some other historians ${ }^{3}$ and my own experiences, this article briefly reflects on the state of local history in Australia and the role of local historical societies. The focus is on New South Wales and the Northern Territory, the parts of Australia that I know best, but some attention is also given to the rest of the country.

Stannage studied at the University of Western Australia during the 1960s under Frank Crowley, ${ }^{4}$ who believed that one of the historian's principal obligations was 'to mine the local ore and thereby demonstrate the interests and techniques of the professional historian' ${ }^{5}$ Crowley published on Western Australian local history, served on the Council of the Royal Western Australian Historical Society and explored much of the state on his motorbike. ${ }^{6}$ He saw national history having its 'proper position at the apex of a historical triangle built up on the broad base of district or local history ${ }^{\prime 7}$ and impressed this view on his students both in Perth and later in Sydney. ${ }^{8}$ It was from Crowley that Stannage would also have learned of the need to develop and document local history archives, an area in which the former was particularly active. ${ }^{9}$

Although Stannage completed his doctoral thesis at the University of Cambridge on the 1935 British general election, his first intention was to work on a local history of the English city of Norwich. It was only after he found that he could not as an outsider properly come to terms with the Norwich story that he changed to another topic. ${ }^{10}$ On returning to the University of Western Australia as a staff member he resumed his local history interests in the early 1970s. They were perhaps most prominently reflected in carefully researched books like The People of Perth, which focuses on Western Australia's capital until the early twentieth century, ${ }^{11}$ and Lakeside City, a study of the more recently developed regional city of Joondalup that is within the Perth metropolitan area. ${ }^{12}$ The West Australian's obituary of him remarked that The People of Perth won wide favour because it 'told stories of ordinary folk, not just grand families'. ${ }^{13}$ Local history was included in the extraordinarily popular first year subject that he taught on colonial Australia, he supervised theses on Western Australian local topics and he used his roles such as foundation chair of the Heritage Council of Western Australia to advance local historical studies. ${ }^{14}$

Stannage's work with local historical societies was highlighted in 1974 when he cooperated with the Subiaco Historical Society in Perth in convening a pioneering and highly successful seminar on local history research methods that brought together academic and community historians and resulted in his much used edited collection of papers Local 
History in Western Australia. The seminar drew, he wrote, 'shire and city councillors; librarians; schoolteachers; Royal Historical Society members; staff and students from tertiary institutions; housewife historians; journalists; and so on' from various parts of the state. Many dedicated and enthusiastic local historians like those at the seminar, Stannage further commented, were already engaged 'in the challenging and exciting task of reconstructing Westralia's past' ${ }^{15}$ With Nan Phillips in 1979 he co-authored the chapter on local historical societies in the Handbook for Aboriginal and Islander History that pointed to the considerable value of society collections and publications in documenting the Australian Indigenous past. It also highlighted the role of society members in collaborating with other historians on aspects of that past. 'Most historical societies have several members whose special interest is Aboriginal history' who were usually 'only too pleased to assist other researchers' Phillips and Stannage noted at a time when this was not widely acknowledged among their academic colleagues. ${ }^{16}$

Stannage was a strong advocate for the community in and identity of the suburb of Subiaco where he was born and lived for many years. In 2001 he published a comprehensive history of his own federation house there. ${ }^{17}$ In June 2011 he was a leading figure in the campaign against a proposed merger of the Subiaco and Nedlands Councils. Subiaco, he and others contended, 'was too special to lose'. ${ }^{18}$ Shortly before his death in October 2012 he spoke at a public forum protesting about planned local government changes in Western Australia, emphasising the threat they posed to community democracy in Subiaco. ${ }^{19}$ A City of Subiaco local history award is now named after him. It is for a report, with images and text, documenting past residents and / or events that relate to a Subiaco house. $^{20}$

Early in 2011, I participated in the commemoration of the Hunters Hill Historical Society's fiftieth anniversary and the Hunters Hill Municipality's sesquicentenary that led to a consideration of Stannage's views and what Bill Gammage describes as the 'dynamic of local history' ${ }^{21}$ Both anniversaries were obviously significant milestones worthy of celebration. A small suburb bordering the north shore of Sydney Harbour, Hunters Hill stands out as being not only an important historic area but also one where over a long period residents ensured the preservation of key elements of their heritage and history. The Historical Society's establishment in 1961 resulted in the development of a remarkable repository of artefacts, documents and images covering Hunters Hill's evolution from its long period as the land of the Wallumedegal people to the present day. Linda Emery's recent history of the suburb shows how for over a century it was a vital hub for heavy 
engineering and shipbuilding. It was also the home of an unusual number of French and Italian residents and some distinguished contributors to Australia's cultural life. Many of its buildings are listed on Commonwealth and state heritage registers. The suburb was the location of what is often seen as the world's first Green Ban in 1971 that protected Kelly's Bush and it remains well known for its community activism. Despite some losses, Hunters Hill has been better in preserving much of its built heritage, particularly its early stone buildings set in leafy gardens and streets, than many other parts of Sydney. These elements ensure that it remains a desirable although now expensive place in which to live. ${ }^{22}$

An examination of Hunters Hill's past prompts the question as to why the work of local historians and historical societies such as that in Hunters Hill matters in understanding the bigger picture of Australian history. The various attempts to tell the stories of individual communities like Hunters Hill, quite frequently by and for local residents themselves, encourage speculation on their contributions to the broader process of historical inquiry.

As Graeme Davison explains, publication of local histories in Australia rarely occurred before the gold rushes of the 1850s. After them, as what was known as the gold generation aged, pioneers wrote their reminiscences and journalists compiled substantial histories of the gold towns. By the late nineteenth century, Australian local histories were becoming more common. They tended to be stories of material and social progress. They had what Davison calls 'long lists of firsts' - the first European 'discovery', the first river crossing, the first school and so on. In doing so, they established a record for communities still in the process of being formed. Some at least briefly discussed Aboriginal people. Many of the histories are anecdotal and badly organised but the best of them include what Davison describes as 'powerful evocations of past landscapes'. ${ }^{23}$

It was against this background that the earliest Australian state and local historical societies were founded. The Royal Australian Historical Society, which despite its name is essentially a New South Wales organisation, began in Sydney in 1901 but the first local society to affiliate with it, the Clarence River Historical Society, did not do so until 1935. Three more affiliated before the Second World War. Their members wanted to promote what they regarded as the local lessons of history, often with cairns and monuments that commemorated events, people and anniversaries and through collections of documents, artefacts and images. Between the two world wars, local history boosted communities' 
self-esteem and encouraged the 'pioneer myth' that Stannage contended in 1985 was used to justify invasion. People who had left their towns and suburbs to live in other places were encouraged to re-visit them in the 'back to' celebrations that Richard White has researched. The published programs for these usually contained short histories illustrated with photographs. $^{24}$

Big changes came after the Second World War, when professionally trained historians entered the field. The young Geoffrey Blainey, who in 1954 published a history of Mount Lyell in Tasmania, ${ }^{25}$ famously attacked what he called the 'scissors and paste' methods of amateur local historians. ${ }^{26}$ Municipal centenaries saw the establishment of many more historical societies and greater opportunities in local history for new graduates. ${ }^{27}$ Between 1950 and the present, hundreds of New South Wales local societies were established..$^{28}$ As Louise Prowse shows, by the 1960s historical societies were showing a genuine interest in Aboriginal history, an interest that came before most academic research in this area. ${ }^{29}$ The Darwin based Historical Society of the Northern Territory started in 1964. Jeremy Long, a young honours graduate in History from the University of Sydney, was its first President. Other Territory historical societies later emerged, including one at the Aboriginal community of Hermannsburg. ${ }^{30}$

Academically trained historians such as Alan Atkinson writing on Camden, Pauline Curby on Randwick, Grace Karskens on The Rocks and Carol Liston on Campbelltown in New South Wales, ${ }^{31}$ and Leith Barter on Nightcliff and Rapid Creek, Mickey Dewar on Darwin, Eve Gibson on Fannie Bay and Darrell Lewis on the Victoria River District in the Northern Territory ${ }^{32}$ all published notable, sometimes commissioned, contributions to local history. They are usually more analytical than earlier accounts, giving attention to themes such as the lives of Aboriginal people and social conflict. Many of these authors were also active historical society members. Liston, for instance, was President of the Royal Australian Historical Society and did much work over a long period with local societies. For many years a Council member of the Historical Society of the Northern Territory, Gibson was co-founder of the Fannie Bay History and Heritage Society. ${ }^{33}$

An outstanding publication illustrating recent approaches to Australian local history is Darrell Lewis's 2012 book A Wild History, which deals with the Northern Territory's remote Victoria River District between the 1880s and the early 1900s. Its emphasis is on early Aboriginal-European contacts and the formation of a settler society. There is a thematic focus on the 'various moments and types of early contact between Aborigines and whites, and the formation of a local 
settler society' ${ }^{\prime 34}$ The district's physical environment, its Aboriginal people before contact with Europeans and its pastoral industry are all covered in considerable depth. A chapter on the ruggedly beautiful Jasper Gorge conveys a powerful sense of place. The book is based on a thorough examination of relevant sources, including many hard-tolocate unpublished materials and interviews. Its narrative is clear and strong with an absence of technical language, making $A$ Wild History accessible to a wide audience. Lewis has a doctorate in History from The Australian National University but has also been a very frequent visitor to the Victoria River District for more than 30 years. His meticulous research combined with extensive first-hand knowledge of locations and people result in a study already widely recognised as a major historical work. ${ }^{35}$

By the 1960s local history played a pivotal role in residents' efforts to conserve historic towns, suburbs and neighbourhoods. While in the 1950s the battle to preserve the built heritage concentrated on early colonial mansions, by the 1960s and 1970s, when Stannage first became actively involved in the heritage movement, interest extended to Aboriginal occupation sites, factories, cinemas, gardens, small cottages and even bus and tram stops. Commonwealth, state and territory parliaments passed heritage legislation that offered some protection to these places. ${ }^{36}$

Stannage's significant work with other historians during the early 1990s on the identification of historic themes for the Commonwealth's Register of the National Estate both reflected and contributed to the process. Their recommended themes aimed at 'comprehending the totality of natural and human history of this continent from the earliest times to the present day' and emphasised the development of ways of life. ${ }^{37}$ Historical societies, engaged in what Tom Griffiths calls the 'assertion of provincial dignity and distinctiveness', ${ }^{38}$ set up museums and resource centres that provided those interested in conserving the physical elements of the past with essential information that they needed to do so. ${ }^{39}$ Local identity, Griffiths writes, 'was often forged from collections of paper and things' ${ }^{40}$

According to the Federation of Australian Historical Societies, in 2012 there were about 100,000 people in Australia who belonged to historical societies, most of which had a local focus. ${ }^{41}$ In 2010 Paul Ashton and Paula Hamilton estimated the total membership at approximately $50,000^{42}$ but that figure may be too low. In 2012 there were over 37,000 members of New South Wales societies affiliated with the Royal Australian Historical Society. ${ }^{43}$ Societies ranged greatly from small 
groups of mainly elderly people who gathered together only occasionally to much more vigorous organisations that met several times a month, organised excursions, published books and journals, owned or managed buildings and research collections, had their own websites and employed staff. While the biggest and best-established societies were those like the Royal Australian Historical Society and the Royal Historical Society of Victoria that had a state or territory role, they frequently provided outreach services such as insurance, newsletters and workshops for their smaller locally based affiliates. There were also some large and prosperous local history bodies.

The Blue Mountains Historical Society at Wentworth Falls in New South Wales owned a big block of land that included an impressive resource and research centre, a lecture theatre and dining facilities. Among its members were many History graduates. Audiences of more than 50 usually attended its lectures. ${ }^{44}$ On the other hand, the once flourishing Auburn Historical Society in Sydney before ceasing to exist was reduced to about half a dozen elderly members whose sole activity was an Annual General Meeting. ${ }^{45}$ There were, as well, instances of societies being reborn. Due to an ageing and declining membership the Mosman Historical Society in Sydney was disbanded in 1995 but an energetic group of new members successfully revived it four years later. In 2013 it had regular well-attended activities and an increasing membership of 140. Indigenous history loomed quite large among its interests. ${ }^{46}$ The more successful societies often had positive relationships with their local councils. The Randwick City Council in Sydney, for instance, provided its local society with extensive premises at no cost. ${ }^{47}$ Many societies were founded in the 1950s and 1960s, so the Hunters Hill society is one of a large number to have celebrated its half-century.

In spite of their successes, local history and local historical societies in Australia face formidable challenges. In his much discussed 2000 book Bowling Alone, Robert D. Putnam showed how during the late twentieth century Americans became increasingly disconnected from family, friends, neighbours and democratic structures. They also belonged to far fewer organisations. He warned that the trend was impoverishing communities and lives. ${ }^{48}$ Some observers contend that a similar situation occurred and is continuing in Australia, especially with young adults' membership of community groups. Many of those involved in Australian community heritage and history organisations during the 1970s and 1980s were aged in their 20s, 30s and 40s. Carol Liston first became President of the Royal Australian Historical Society in 1988 at the age of $36 .{ }^{49}$ Today that is much less common. As early as 2000, William Tyler's comprehensive survey of Australian historical societies 
emphasised the urgent need for them to recruit new and younger members. ${ }^{50}$ Few of the approximately 120 attendees at the Royal Australian Historical Society's 2012 affiliated societies conference were under the age of $60 .{ }^{51}$ Competing activities, new forms of social media like Facebook and Twitter that numerous historical societies still do not use and the demands of modern work places are all factors here ${ }^{52} \mathrm{~A}$ further problem is that partly due to local history's expanded visibility and the diverse uses to which it is put, researching the local past increasingly occurs online and is being quite rapidly commercialised. Ancestry.com.au, for example, although mainly intended for family historians, is a vast, much used and quickly expanding local history resource that charges high subscription fees. ${ }^{53}$

Such challenges can and should be met. One of the greatest benefits of local history in early twenty-first-century Australia is that it helps provide increasingly mobile populations whose traditional values are sometimes hard to define with a sense of place and purpose. This is very much the case in the Northern Territory, where Indigenous people comprise about a third of the population and an especially large proportion of the non-Indigenous residents is from other parts of Australia and the world. ${ }^{54}$

The Territory's governments have long recognised the value of promoting interest in local heritage and history as a means of encouraging a sense of belonging. ${ }^{55}$ Local histories published by the Historical Society of the Northern Territory are generally the stories of frontier communities ${ }^{56}$ linked together by what Alan Powell identifies as the common themes of 'isolation from the rest of the continent, nearness to Asia, location in the tropics...the powerful influence of Aborigines' and 'the long colonial experience'. ${ }^{57}$ What Stannage saw as the pioneer myth still receives some support in the Territory but its influence is diminishing. Throughout Australia local history is incorporated into strategies concerned with education, museums, national parks and tourism. There is a quite widespread recognition among decision makers that an understanding of the local past tells people much that is worthwhile about their own communities or places that they visit and themselves. ${ }^{58}$ As Stannage hoped it would, the development of academic and professional history encouraged many local historians and societies to seek more sophisticated ways of collecting, preserving, presenting and using a complex variety of materials.

Although historical societies vary greatly and some are in far better condition than others, their total membership mentioned earlier shows that the local history movement in Australia remains in reasonable 
health. The societies also make a material contribution to national well being that is all too frequently overlooked. The Federation of Australian Historical Societies conservatively estimated in 2012 that Australian historical society members undertook about $\$ 54$ million worth of voluntary work each year. ${ }^{59}$ The 1979 English Committee to Review Local History sensibly suggested that its growth and popularity were 'rooted in social and psychological needs brought on by rapid change in environment and life style'. ${ }^{60}$ Further recent factors include more people receiving post-school education, physically active retired people seeking to fill their leisure time, the increased availability, especially through digitisation and the Internet, of historical records and the worldwide boom in family history.

All these factors are good for local history and many of the community organisations that promote it. It is, as Stannage strongly believed it ought to be, usually a democratic phenomenon and one that allows a diverse range of approaches. Organisations like the Hunters Hill Historical Society survive and develop because they are solidly based in their communities. Perhaps even more crucial, the data of the past that local historical societies have often unearthed and recorded help allow Australians to shape what Stannage so aptly described as a 'history for their own purposes of identity'. ${ }^{61}$

Some material in this article mainly relating to New South Wales also appears in author David Carment, 'Local history and local historical societies in twenty first century Australia', History, 2012, no 112, pp2-3.

\section{ENDNOTES}

${ }^{1}$ Tom Stannage (ed), Local History in Western Australia (A Guide to Research): Papers Read at the Local History Seminar Held at Subiaco on 29 August 1974, Department of History, University of Western Australia, nd, p1.

${ }^{2}$ C. T. Stannage, The People of Perth: A Social History of Western Australia's Capital City, Perth City Council, Perth, 1979, pp8-9.

${ }^{3}$ Previous discussions of Australian local history include: Paul Ashton and Paula Hamilton, History at the Crossroads: Australians and the Past, Halstead Press Ultimo, 2010, ch3; B. J. Dalton (ed), Peripheral Visions: Essays on Australian Local and Regional History, Department of History and Politics, James Cook University, Townsville, 1991; Locating Australia's Past: A Practical Guide to Writing Local History in New South Wales, The Local History Co-ordination Project and The University of New South Wales, Sydney, 1988; Richard Waterhouse, 'Locating the New Social History: Transnational Historiography and Australian Local History', Journal of the Royal Australian Historical Society, vol 95, no 1, 2009.

${ }^{4}$ Lyall Hunt, 'Larrikin Historian: Remembering Frank Crowley in Western Australia, 1949-1964', unpublished paper held by author, 2010, p9.

${ }^{5}$ F. K. Crowley, Australia's Western Third: A History of Western Australia, Heinemann, Melbourne, 1970 (first published 1960), back cover.

${ }^{6}$ Hunt, op cit. 
${ }^{7}$ F. K. Crowley, 'Problems in Local and Regional History', Early Days, vol 5, no 2, 1956, p25.

${ }^{8}$ The author studied under Crowley at the University of New South Wales.

${ }^{9}$ Hunt, op cit.

${ }^{10}$ Part of a recorded interview with Tom Stannage played at the Australian Historical Association Conference, Wollongong, 2013.

${ }^{11}$ Stannage, The People of Perth, op cit.

${ }^{12}$ C. T. Stannage, Lakeside City: The Dreaming of Joondalup, University of Western Australia Press, Nedlands, 1996.

${ }^{13}$ West Australian, 5 October 2012.

${ }^{14}$ Carment, 'An Unfinished Journey'. Also see Tom Stannage - Wikipedia, the free encyclopedia, http:/ / en.wikipedia.org/wiki/Tom_Stannage (accessed 27 June 2013).

${ }^{15}$ Stannage, Local History in Western Australia, op cit, pp1-2.

${ }^{16}$ Nan Phillips and Tom Stannage, 'Historical Societies', in Diane Barwick, Michael Mace and Tom Stannage (eds), Handbook for Aboriginal and Islander History, Aboriginal History, Canberra, 1979, p77.

${ }^{17}$ Tom Stannage, 'The Federation House: 8 Chester Street Subiaco', in Susan Marsden (ed), Our House: Histories of Australian Homes, Australian Heritage Commission, Canberra, 2001,

http:/ / www.environment.gov.au/heritage/ahc/ publications/commission/books / ourhouse/wa02.html (accessed 27 June 2013).

${ }_{18}$ West Australian, 14 June 2011.

${ }^{19}$ WSA Public Forum I Local. Govt and Subiaco, http:/ / localgovtsubiaco.wordpress.com/2012/10/11/wsa-public-forum/ (accessed 30 July 2013).

${ }^{20}$ Oonagh Quigley and the City of Subiaco, 'Subiaco Local History Awards Monday 5 November 2012', Newsletter History Council of WA, vol 8, no 4, 2012.

${ }^{21}$ Bill Gammage, 'A Dynamic of Local History', in Dalton, op cit.

${ }^{22}$ Discover Hunters Hill, http:/ / www.huntershill.nsw.au/subsites/index.asp?id=508 (accessed 27 June 2013); Linda Emery, Pictorial History Hunters Hill, Kingsclear Books, Sydney 2012.

${ }^{23}$ Graeme Davison, 'Local History', in Graeme Davison, John Hirst and Stuart Macintyre (eds), The Oxford Companion to Australian History, Oxford University Press, Oxford, 1998, p397.

${ }^{24}$ Don Garden, 'Historical Societies', in Davison, Hirst and Macintyre, op cit, p318; Alfred James (ed), Much Writing, Many Opinions: The Making of the Royal Australian Historical Society 1901 to 2001, The Royal Australian Historical Society, Sydney, 2001; C. T. Stannage, Western Australia's Heritage: The Pioneer Myth, University Extension, University of Western Australia, Nedlands, 1985; A Public Lecture by Dr Richard White, http: / / artsonline.monash.edu.au/news-events/a-publiclecture-by-dr-richard-white (accessed 27 June 2013).

${ }_{25}$ Geoffrey Blainey, The Peaks of Lyell, Third Edition, Melbourne University Press, Melbourne, 1967 (first published in 1954).

${ }^{26}$ Geoffrey Blainey, 'Scissors and Paste in Local History', Historical Studies Australia and New Zealand, vol 6, no 23, 1955.

${ }^{27}$ Davison, op cit, pp397-398.

${ }^{28}$ Mari Metzke, 'Affiliated Societies of the RAHS', in James, op cit, pp104-122.

${ }^{29}$ Louise Prowse, 'Parallels on the Periphery: Aboriginal History and Local History', paper presented to the Australian Historical Association Conference, Wollongong, 2013.

${ }^{30}$ Earl James AM, The Historical Society of the NT: Early Days, Historical Society of the Northern Territory, Darwin, 2008.

${ }^{31}$ Alan Atkinson, Camden: Farm and Village Life in Early New South Wales, Revised Edition, Australian Scholarly Publishing, Melbourne, 2008; Pauline Curby, Randwick, Randwick Municipal Council, Randwick, 2009; Grace Karskens, The 
Rocks: Everyday Life in Early Sydney 1788-1830, Melbourne University Press, Melbourne, 1998; Carl Liston, Campbelltown: The Bicentennial History, Allen \& Unwin, Sydney, 1988.

${ }^{32}$ Leith F. Barter, From Wartime Camp to Garden Suburb: A Short History of Nightcliff and Rapid Creek, Historical Society of the Northern Territory, Darwin, 1994; Mickey

Dewar, No Place Like Home: Australia's Northern Capital in the 1950s through a Social History of Housing, Historical Society of the Northern Territory, Darwin, 2010; Eve Gibson, Beyond the Boundary: Fannie Bay 1869-2001, Historical Society of the Northern Territory, Darwin 2011; Darrell Lewis, A Wild History: Life and Death on the Victoria River Frontier, Monash University Publishing, Clayton, 2012.

${ }^{33}$ Personal knowledge.

${ }^{34}$ Lewis, op cit, pxxi.

${ }^{35}$ ibid. The book was reviewed in Aboriginal History, vol 36, 2012, pp213-14. See also David Carment, 'Local history and local historical societies in twenty first century Australia', History, 2012, no 112, pp2-3.

${ }^{36}$ Graeme Davison, 'A Brief History of the Australian Heritage Movement', in Graeme Davison and Chris McConville (eds), A Heritage Handbook, Allen and Unwin, Sydney, 1991.

${ }^{37}$ Norman Etherington, Penny Brock, Tom Stannage, Jenny Gregory with Jane Lennon, 'Principal Australian Themes Project. Stage 1 Draft Report for Circulation and Discussion. Uses and Identification of Principal Historical Themes: Volume 1, Report of Findings', Centre for Western Australian History, University of Western Australia, Perth, nd (1993), pp1-11.

${ }^{38}$ Tom Griffiths, Hunters and Collectors: The Antiquarian Imagination in Australia, Cambridge University Press, Cambridge, 1996, p222.

${ }^{39}$ Davison, 'A Brief History of the Australian Heritage Movement' op cit.

${ }^{40}$ Griffiths, op cit, p222.

${ }^{41}$ Federation of Australian Historical Societies - E-Bulletin_98, http:/ / www.history.org.au /E-Bulletin_98.html (accessed 27 June 2013).

42 Ashton and Hamilton, op cit, p 41.

${ }^{43}$ Information provided to author by Chief Executive Officer, Royal Australian Historical Society, June 2012. This figure is reasonably accurate as it was required for the affiliated societies insurance scheme. Each affiliated society seeking insurance has to provide the Royal Australian Historical Society with its up to date membership.

${ }^{44}$ ibid. Also see Blue Mountains Historical Society Inc, http:/ / bluemountainshistory.com/ (accessed 27 June 2013).

${ }_{45}$ Oral communication, Auburn Historical Society office bearer, 2010.

${ }^{46}$ Frequent visits to Mosman Historical Society since 2007. Also see Welcome I Mosman Historical Society. http:/ / mosmanhistoricalsociety.org.au/ (accessed 27 June 2013).

${ }^{47}$ Visit to Randwick and District Historical Society in 2010. Also see Randwick \& District Historical Society, http:/ / www.randwickhistoricalsociety.org.au/ (accessed 29 July 2013).

${ }^{48}$ Robert D. Putnam, Bowling Alone: The Collapse and Revival of American Community, Simon and Schuster, New York, 2000.

${ }^{49}$ Anne-Maree Whitaker, 'Biographical Notes on the Fellows of the RAHS', in James, op cit, pp77-78.

${ }^{50}$ William Tyler, 'Survey 2000. The Federation of Australian Historical Societies: A report of the 2000 Survey of Members', 2000, np.

${ }^{51}$ Attendance at conference.

52 These comments are based on the author's active participation in the Australian community history movement since the 1970s.

${ }^{53}$ Genealogy, Family Trees and Family History records online - Ancestry.com.au, http:/ / home.ancestry.com.au (accessed 27 June 2013). 
${ }^{54}$ David Carment, A Past Displayed: Public History, Public Memory and Cultural Resource Management in Australia's Northern Territory, Northern Territory University Press, Darwin, 2001, ch2.

${ }^{55}$ David Carment, Territorianism: Politics and Identity in Australia's Northern Territory 1978-2001, Australian Scholarly Publishing, Melbourne, 2007, ch1.

${ }^{56}$ Publications of HSNT, http: / / www.historicalsocietynt.org.au/services.htm (accessed 27 June 2013).

${ }^{57}$ Alan Powell, 'Northern Territory', in Graeme Aplin, S. G. Foster and Michael McKernan (eds), Australians: A Historical Dictionary, Fairfax, Syme and Weldon Associates, Sydney, 1987, p303.

${ }^{58}$ This is recognised in the annual promotion of Australian Heritage Week. See Australian Heritage Week I Department of Sustainability, Environment, Water, Population and Community, http:/ / heritage-week.govspace.gov.au/ (accessed 27 June 2013).

${ }^{59}$ Federation of Australian Historical Societies, op cit.

${ }^{60}$ Quoted in Carol Kammen, On Doing Local History: Reflections on What Local Historians Do, Why, and What It Means, The American Association for State and Local History, Nashville, 1986, p174.

${ }^{61}$ Tom Stannage, 'Introduction', in Barwick, Mace and Stannage, op cit, pxii. 